\title{
G CUBED MODEL ANALYSIS: THE IMPACT OF LOSS OF CONFIDENCE IN EMERGING COUNTRIES ON THE WORLD ECONOMY
}

\author{
Ardi Sugiyarto \\ Fiscal Policy Agency, Ministry of Finance Indonesia \\ Email: ardi.sugiyarto22@gmail.com \\ Received: May 2019; Accepted: June 2019; Available online: July 2019
}

\begin{abstract}
Financial liberalization has significant role in fostering economic growth in the developing countries. However, it also cause a risk for the emerging countries when the advanced countries make an interest rate adjustment. This paper try to examine the economic adjustment both on emerging countries and advanced countries in response to the shift of risk perception in emerging countries. This study will simulate the shock of risk perception in emerging countries by using intertemporal general equilibrium economic model that are called G-Cubed Model. The simulation result from the model indicates that international financial flow has a significant role in explaining the spill over effect of the lost confidence in emerging countries. In the short run, there is a significant drop in consumption and private investment in emerging countries. In the long run output of the emerging countries is expected steady below the baseline. On the other hand, in advanced countries, there is a significant increase in private consumption and investment in the short run. Moreover, it is expected that lower interest rate stimulates the investment in the future in advanced countries.
\end{abstract}

Keywords: G-Cubed, emerging, simulation, risk, financial flow

\begin{abstract}
Abstrak
Liberalisasi keuangan memiliki peran penting dalam mendorong pertumbuhan ekonomi di negara-negara berkembang. Namun, liberalisasi keuangan juga akan menimbulkan risiko bagi negara-negara berkembang ketika negara-negara maju melakukan penyesuaian suku bunga. Penelitian ini bertujuan untuk melakukan analisis dampak dari pergeseran persepsi risiko baik bagi negara-negara berkembang maupun negara-negara maju. Studi ini akan mensimulasikan pergeseran persepsi risiko di negara-negara berkembang dengan menggunakan model ekonomi keseimbangan umum antarwaktu yang disebut Model G-Cubed. Hasil simulasi dari model menunjukkan bahwa aliran keuangan internasional memiliki peran yang signifikan dalam menjelaskan efek tumpahan dari hilangnya kepercayaan di negaranegara berkembang. Dalam jangka pendek, ada penurunan konsumsi dan investasi swasta yang signifikan di negara-negara berkembang. Dalam jangka panjang, output dari negaranegara berkembang diperkirakan stabil di bawah baseline. Di sisi lain, di negara maju, ada peningkatan konsumsi dan investasi swasta yang signifikan dalam jangka pendek. Selain itu, diharapkan suku bunga yang lebih rendah merangsang investasi di masa depan di negaranegara maju.
\end{abstract}

Kata Kunci: G-Cubed, negara emerging, simulasi, risiko, arus keuangan

How to Cite: Sugiyarto, A. (2019). G Cubed Model Analysis: The Impact of Loss of Confidence In Emerging Countries on The World Economy. Media Ekonomi dan Manajemen, 34(2), 164-177. 


\section{INTRODUCTION}

Financial liberalization is commonly considered as one of the key elements which have a significant role in fostering economic growth in the developing countries. Prasad, Rogoff, Wei, \& Kose, M (2003) argue that financial liberalization directly affects domestic saving and cost of capital. Moreover, financial liberalization can also promote efficiency through specialization and improve macroeconomic policies and institution through global competitive pressures. However, the experience from the Asian crisis in 1997 shows that financial liberalization is not always necessary for the economy. (Calvo, Leiderman, \& Reinhart, 1996) argue that financial liberalization causes excessive capital inflow in developing countries which it may not be allocated to the productive investment. Therefore, the economy will suffer the financial instability and moreover economic instability.

Recently, the role of financial liberalization in the economy can be captured by observing financial and capital mobility during the global financial crisis. After the global financial crisis, private capital inflows to emerging market increased dramatically. It is recorded that private capital inflows to emerging markets surged to over one trillion dollars in 2010. This phenomenon occurs because expansionary monetary policy in advanced countries is prompting investors to seek higher returns in emerging markets. For several years, emerging countries gained the benefit from this capital inflow which is indicated by the currency appreciation, stock market enhancement, and lower bond yield (Grenville, 2011)

Although capital inflow in emerging markets is likely beneficial for emerging countries, this positive effect is not expected to last forever. The US Fed policy change which is aimed to reduce the number of assets purchased may rise volatility on the emerging market.
According to the Institute of International Finance (2014), tapering policy from the US Fed is expected to decline of capital inflows to the emerging market by $\$ 153$ billion to $\$ 1.06$ trillion in 2013. Mishra, Moriyama, N'Diaye, \& Nguyen (2014) argue that the tapering policy will cause market pressure in emerging countries. This IMF study shows that on average emerging countries experienced 3 percent of currency depreciation and 7 percent equities decline in 2013.

The large reverse capital flow from emerging markets indicates that there is a shift of investor's perception in determining their investment. Monetary tightening in advanced countries leads to loss of confidence in emerging countries which is translated as the increase of risk in emerging countries. The emerging countries become riskier because there are a potential future sudden reversal flows which are caused by interest rate adjustment in advanced countries. Economists believe that the sudden stop phenomenon becomes unfavorable for emerging countries because it can lead to the decline of economic activity. Binici \& Yörüko (2011) find that emerging market economies have become increasingly integrated with global financial markets have several sources of vulnerabilities even when it have sound macroeconomic policy.

Considering this problem, it is important to examine the transmission and channel through which shift of risk perception on emerging countries influence the economy. In order to conduct this analysis, we need to apply a global model which fully integrates the real and financial sectors of the economy. The G Cubed model is relevant to be used in this analysis because it can capture simultaneously macroeconomics and sectoral linkages in the domestic and global economy by incorporating trade, financial flows, wealth effect, and expectation. Therefore, by using the G Cubed model, it is expected that we can examine comprehensively the 
impact of the loss of confidence in the emerging market on the global economy.

This paper will focus on examining the economic adjustment in response to the shift of risk perception in emerging countries. The introduction provides the recent phenomenon in the economy that shows the increase of emerging markets risk. The second part of this paper contains a literature review. The third part of this paper outlines the G-Cubed Model which will be used to examine the impact of the loss of confidence in emerging countries. The fourth part explains how to re-evaluate risk and how to incorporate it in the model. The following part provides result simulation from the $\mathrm{G}$ Cubed model that represents a global economic adjustment in response to risk perception adjustment in emerging countries. This part will explore the transmission and impact of the loss of confidence in emerging countries both for emerging market and non-emerging markets. The last part contains the conclusion and policy implication.

\section{LITERATURE REVIEW}

Financial liberalization enables residences across countries to allocate their financial capital to the place which offers the highest expected return. Free capital mobility has a significant role in explaining the spill over effect of shock in one group of countries to the others. Reinhart \& Reinhart (2003) find that there is a strong positive correlation between FDI flows to emerging countries and the economic performance of the US. According to Warnock (2001), the capital flow of market stock in emerging countries is influenced by the level of interest rate and economic growth in the US.

The capital inflow to emerging countries has a positive impact on economic growth since it supports private investment and enhances domestic demand. However, capital inflow in emerging countries also has a potential problem in the future because there is a possibility of a sudden reversal in capital flow. Obstfeld (2012) argues that expectation can be a trigger of the crisis even when the economy is fundamentally strong. The future expectation of people can affect the behavior of the capital flows across the countries. Therefore, any specific shock on the countries will shift the behavior of investors in allocating their financial capital.

Obstfeld (2012) argues that perfect capital mobility forces the investor to maintain the uncovered interest parity so it can lead to the potential sudden collapse in the economy. The characteristic of the financial capital that can be moved instantly basically ensures the absence of arbitrage opportunity in the exchange rate market. However, if there is a shock of the exchange rate then there will be a sudden loss of reserve which can increase the interest rate and currency depreciation.

According to Obstfeld (2002), shock in the exchange rate has price effect and volume effect in the trade balance. In short, there is a potential decline of trade balance because of the dominant effect of the decrease in import. However, in the long term, volume effect has eliminated the price effect so the trade balance becomes surplus because there is a significant increase in export to foreign countries.

Based on these, we can expect that any investors in the world concerns about return so then they will change their portfolio and direct investment in order to adopt the change of market risk perception. The increasing trend of risk perception in emerging countries will lead the increase of risk premia and will be followed by movement of investment and capital fund from emerging to advanced countries. Because of this, it is expected that in near future there a significant declining of the economy in emerging markets while advanced countries enjoy the upward economic trend. In the future, emerging countries economy will remain below the 
baseline while advanced countries will experience positive economic trend.

\section{RESEARCH METHODS}

\section{Data}

In order to examine the impact of risk perception shifting in emerging countries on the world economy, this study will use all macroeconomics data set both from emerging countries and advanced countries that available on World Development Indicators. The historical data that is used for estimations covers all available data from all available countries until the year 2013 .

Historical data set for macroeconomic variables collected from seventeen regions that represent emerging countries and non-emerging countries, A region can be a group of countries or an individual country. Each region consists of six sectors of production and several economic agents which are households, the governments, and the financial sector (Table.1)

Table 1. Countries/Regions and Sectors in G Cubed

\begin{tabular}{lcl}
\hline Regions & Code & Sectors \\
\hline United States & USA & Energy \\
Japan & JPN & Mining \\
United Kingdom & GBR & Agriculture \\
Germany & DEU & Manufacturing Durable \\
Rest of Euro Zone & EUZ & Manufacturing non-durables \\
Canada & CAN & Services \\
Australia & AUS & \\
Korea & KOR & \\
ROECD & OEC & \\
China & CHI & \\
India & IND & \\
Indonesia & INO & \\
Other Asia & OAS & \\
Latin America & LAM & \\
Other developing countries & LDC & \\
Eastern Europe and former Soviet Union & EEB & \\
Oil-exporting and the Middle East & OPC & \\
\hline
\end{tabular}

\section{Simulation Framework}

Before examining the impacts of the shifting of risk perception on world economics, we first develop a baseline scenario which represents global economic condition in the absence of risk shifting. The baseline that is produced by the model focused on obtaining projections for a few key macroeconomic variables, such as real GDP, market value of manufacturing sector, investment. The baseline scenario is obtained based on the historical data by applying all multisector equations that embedded in the $\mathrm{G}$ Cubed Model. This projection is applied from the year 2014 to 2030 to capture short term and long term analysis framework.

After baseline scenario is obtained then we applied a shock scenario that is formulated based on the arbitrary number of risk shock which is $2 \%$. By applying shock on the G Cubed model, we will obtain alternative projection scenario that is different from the baseline scenario. 
To analyse the impact of shock, the deviation of the alternative scenario from the baseline is calculated each year in the period 2014-2030

\section{G-Cubed Model}

G-Cubed is an intertemporal general equilibrium model which is built based on the modern macroeconomic theory and international trade theory. In the G-Cubed model, the economy is determined by the interaction of all agents in the economy which has intertemporal optimizing behavior (W. J. McKibbin \& Wilcoxen, 2013). One of the advantages of this model is the capacity to capture short term and long term adjustments in the economy. In the short term, this model allows the economy deviates from optimal behavior due to the inability of a firm and household to borrow at risk-free rate (Mckibbin \& Stoeckel, 2009). In the long run, there is only a single equilibrium which represents the steady state of optimizing agent behavior.

One of the key features of the $G$ Cubed model is the distinction made between the financial capital and physical capital in the economy is taken into account. Financial capital is assumed perfect mobile so it can flow immediately to respond to the change of expected return. On the other hand, physical capital is sticky so it cannot be moved immediately across countries or sectors. This distinction will lead to the differences between available physical capital in the economy and its valuation because of the decision of economic agents in capital allocation (Allsopp, McKibbin, \& Vines, 2008).

In the $G$ Cubed model financial assets are assumed to be perfect substitutes within a country and internationally which means that asset prices are linked within and between countries. The value of bond and equity in the economy is determined by using the arbitrage equation which is linking the expected rate of change in the price of the asset to the difference between short term and long term return. The $G$ Cubed uses the uncovered interest parity equation which uses a different domestic and foreign interest rate and exogenous risk premia to determine the exchange rate.

The advantage of using $G$ Cubed to modelling global economic is because it provides analysis on sectoral detail. Moreover, the model is able to link countries and regions through trade and financial markets. The rich analysis of financial flow across countries allows us to examine the consequences of the change of risk so it is very useful to explain the current economic phenomenon and policy debate on trade and international capital flows.

\section{Modelling the Change of Risk in the Emerging Market}

The baseline of the $\mathrm{G}$ Cubed model represents the steady state condition without any shock in the economy which is generated by applying intertemporal optimization. The baseline is built by using several exogenous assumptions and rational expectations rule in the estimation. In this paper, the shock of risk in emerging countries is imposed in 2014. Because of this shock, the economy will be affected immediately and then move on the path toward a steady state in the future.

The loss of confidence in the emerging countries can be represented as an increase of risk premium which influence the capital allocation of investors. For this reason change risk is modelled by considering the real interest parity equation which is represented as follows:

$$
r_{t}^{i}=r_{t}^{u}+{ }_{t} e_{t+1}-e_{t}+\xi_{t}
$$

That equation shows that real interest rate of short term government bond should be equal the interest rate in the US in the same period which adjusted by expected depreciation bilateral real exchange rate and the exogenous risk premium $\left(\xi_{t}\right)$. The risk premium represents a wide range of 
factors, for example, restriction of financial flow and sovereign risk (Mckibbin, 1998). By using equation (1) we can solve the exchange rate $\left(e_{t}\right)$ as follows:

$$
e_{t}=\int_{t}^{T}\left(r_{s}^{U}-r_{s}+\xi_{s}\right) d s+{ }_{t} e_{T}
$$

From the equation, we can know that real exchange rate can be determined by sum differential of the expected future interest rate and risk premiums on assets denominated in domestic currency plus the value of real exchange rate in the equilibrium. The constant value of the risk premium in the baseline should be equal to the value such that exchange rate $\left(e_{t}\right)$ converted into nominal adjusted by price deflator is equal to the observed nominal exchange rate (W. McKibbin, 1998).

In order to simulate the increase of emerging countries, the risk premiums shock is set exogenously. In the simulation, we will assume that risk premium shock in the emerging market lasts forever with an equal magnitude which is $2 \%$ from the baseline. The risk premium shock will affect the determination of the real exchange rate and also interest rate. In the $\mathrm{G}$ cubed risk exchange rate shock lead the depreciation of the domestic currency of emerging countries. Risk shock also increases the required rate return of asset in the emerging countries so both nominal and real exchange rate will also jump up.

\section{RESULT AND DISCUSSION}

In the simulation, we assume that shock occurs at the end of the year 2013 so that the effect will be firstly captured in the year 2014. The increase of risk in emerging countries induces the capital outflow which immediately causes exchange rate depreciation. According to the model, Indonesia, India, Latin America experience the sharp depreciation by more than $15 \%$ from the baseline (Figure 1). This indicates that a rise in risk perception will lead to a big capital outflow from those countries.

Substantial amounts of capital flow from emerging countries lead to an increase in real interest rates in those countries. Figure 1 shows that China's real interest rate soar by more than $2 \%$ from the baseline which is much higher than other emerging countries. This phenomenon indicates monetary policy in China that tries to peg the currency contributing to the boost of interest rate in China. Because the shock of risk is permanent, it is expected that real interest rates in emerging countries will stay above the baseline for subsequent decades.

Because real interest rates become higher, investment is more expensive so after a shock is induced, investment in the emerging countries drops below the baseline. Figure 1 shows that there is a decline in investment in China, India, and Indonesia by between $10 \%$ and $15 \%$ from the baseline. Surprisingly, Latin America countries and other emerging countries in Asia experience a deeper drop in investment which is by about $30 \%$. However, the decrease of the investment will not last forever. Figure 1 shows that investment will recover from the year 2016 and in the future, the investment will converge to the steady-state equilibrium. In addition, the rise in interest rates will cause a decline in expected income in the future. Therefore, to respond to this the households in the emerging countries will reduce their consumption. Figure 1 shows that private consumption in emerging countries declines by between $3 \%$ and $6 \%$ below the baseline in 2014. In the long run, private consumption in emerging countries is consistently below the baseline.

The permanent risk premium shock in emerging countries represents a higher marginal product of capital relative to other countries. In other words, an increase of risk leads to the lower stock of capital in emerging countries. The currency depreciation causes the price of imported 
capital goods in the manufacturing industry to become more expensive. Figure 2 illustrates the change in the stock market value in the manufacturing sector. This figure indicates that residences in emerging market experience loss in capital. Because physical capital asset is immobile, the capital losses are also accompanied by a rise in the cost the financial capital. Overall capital losses in the emerging countries can be represented by the decrease of a total market value stock.

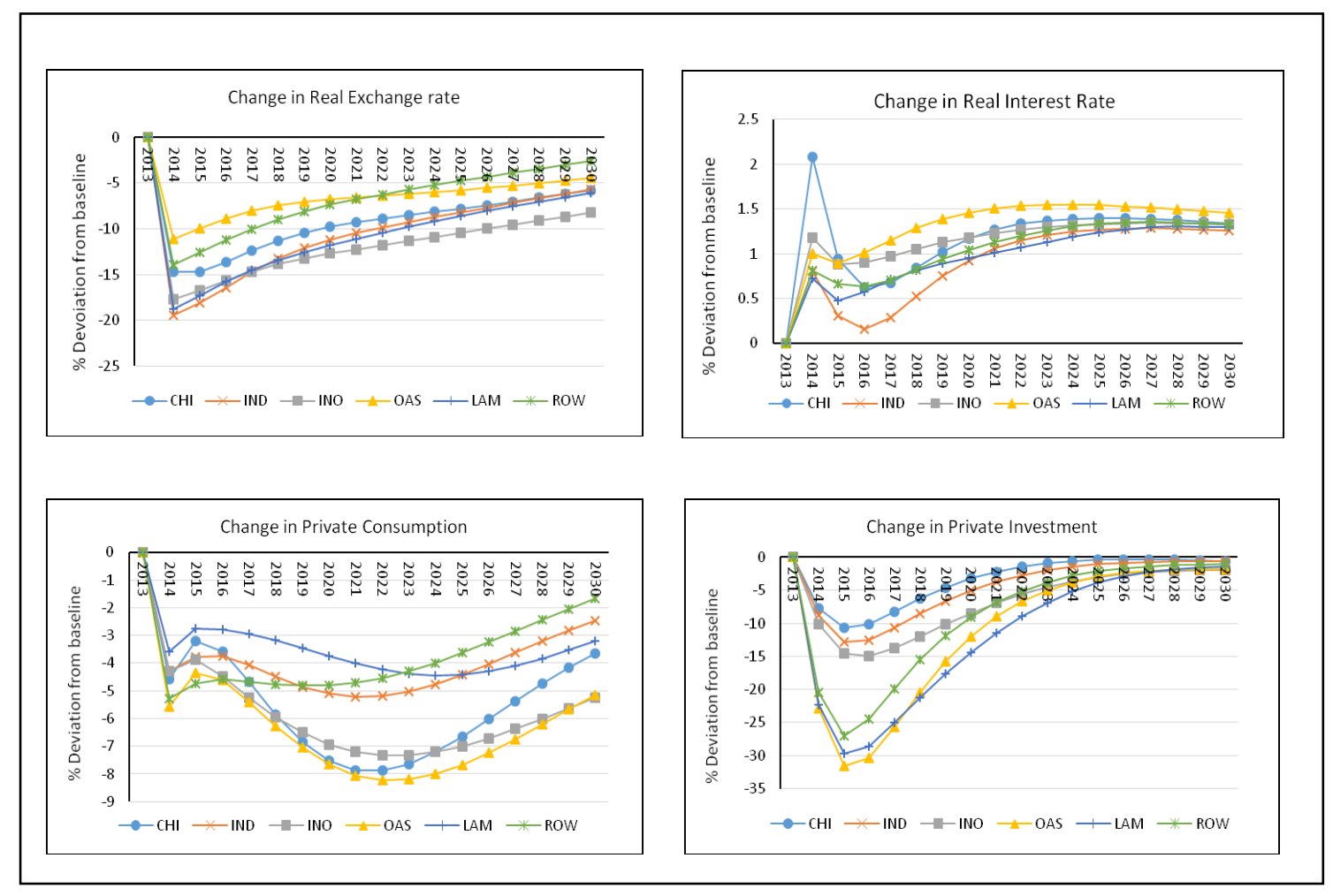

Figure 1. Real Exchange Rate, Real Interest Rate, Private Consumption, and Private Investment of Emerging Countries 


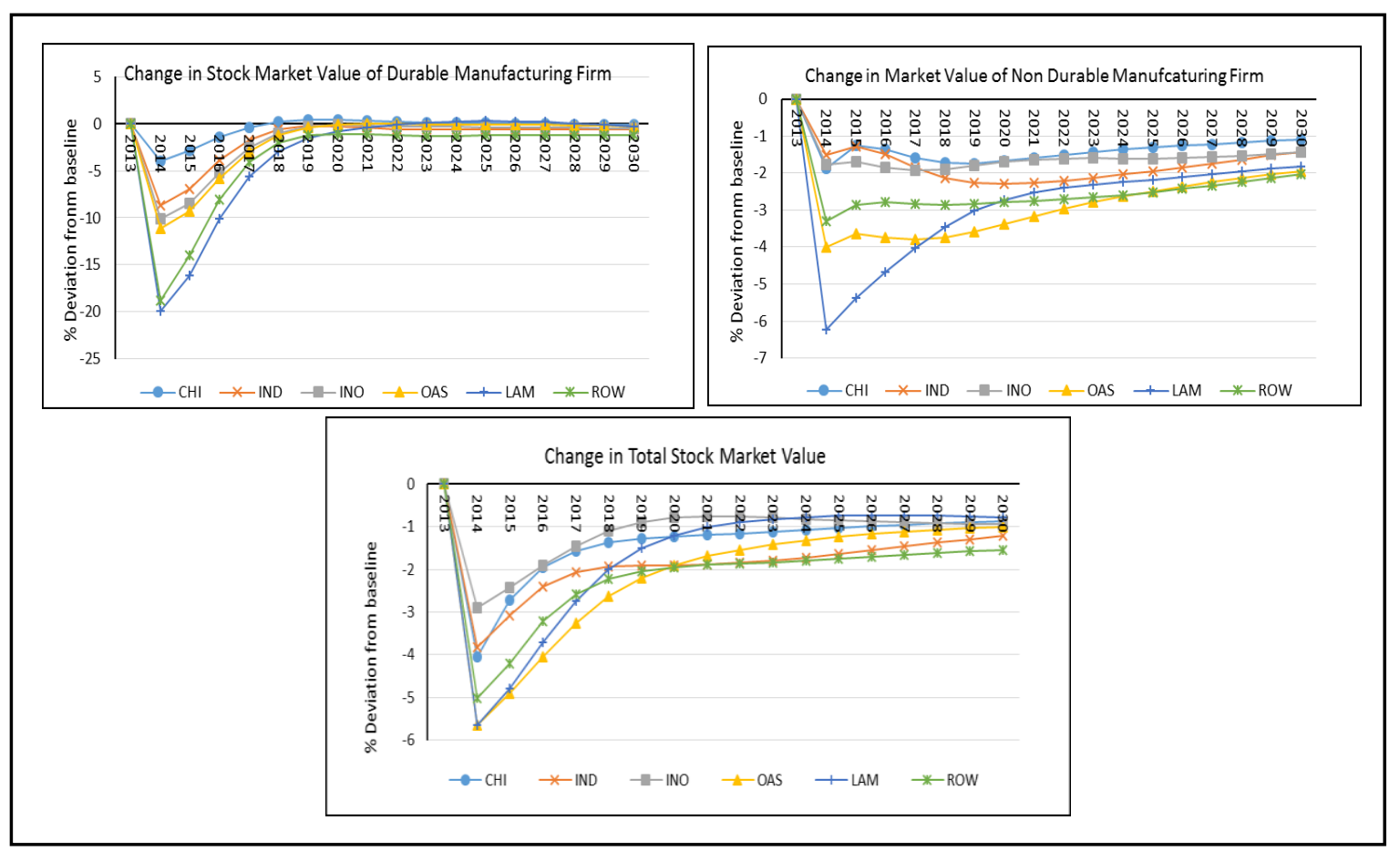

Figure 2. Change in Stock Market Value in Emerging Countries

A combination of the decrease of the demand shock and investments obviously pushes down the GDP in emerging countries. Figure 3 indicates that the output of emerging countries slightly drops from the baseline level. This figure shows that real GDP is not affected significantly even though there is a significant decline in private consumption and investment. In the year 2014, the GDP of emerging countries fall by less than $2.5 \%$ and for the subsequent year, GDP decreases no more than $3.5 \%$ from the baseline. For several years, there will be an economic slowdown in emerging countries. In the long run, the output of the economy will be steady below the baseline.
The decline of real GDP is not substantial because there is a sharp increase in export due to currency depreciation. In Figure 3, we can see that export in China and India rise by about $10 \%$ while Indonesia and Latin America increase more by about $15 \%$ in the year 2014. Even for other emerging countries, export increase by about $20 \%$ from the baseline level. The significant increase in export in emerging countries also can be captured from the surplus of the current account. This condition is likely beneficial for emerging countries because it can reduce the effect of domestic demand drop. However, the current account surplus can also represent that there is an increase in capital 

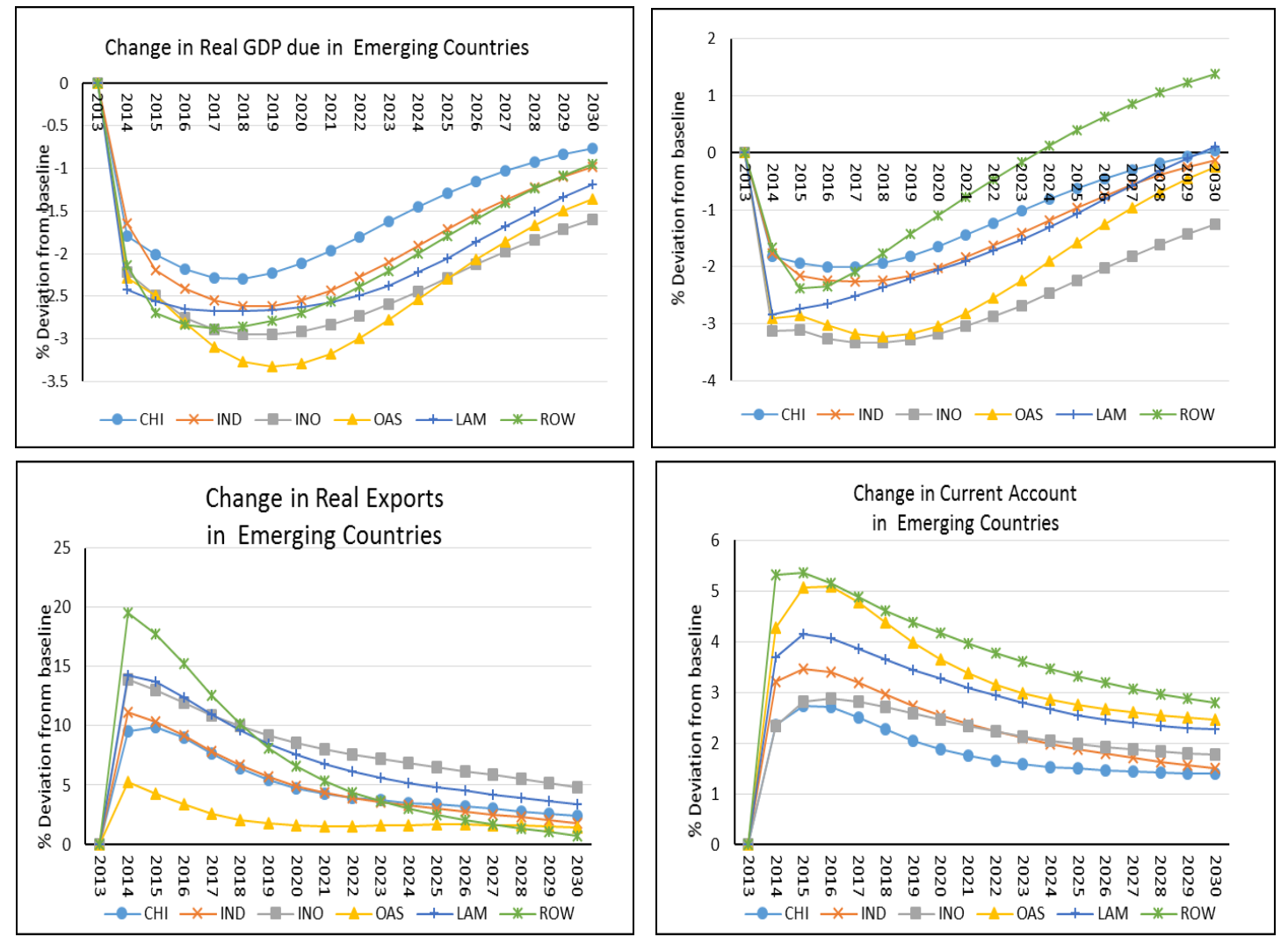

Figure 3. Real GDP, Real GNP, Real Export, and Current Account of Emerging Countries

The spill over effect of the loss of confidence in emerging countries can be analyzed by examining international trade transmission which links the emerging countries and the rest of the world. Firstly, the decline of domestic demand in emerging countries indicates the drop in imports from non-emerging countries. Secondly, a significant rise in the emerging country's export indicates that aggregate demand in non-emerging countries rises significantly. Figure 4 shows that all exports in all OCD countries decrease immediately after risk shock is induced. The export of OECD countries remains below the baseline for decades. The biggest drop in export is experienced by the US and Japan which indicates that these two countries have a big share market in emerging countries.

Transmission from the international trade channel above is to provide the basic intuition to explain the spill over effect of loss of confidence in the emerging market. However, this intuition cannot fully explain this comprehensively because of several reasons. Firstly, emerging countries imports consist of final goods and intermediate goods so the drop in domestic demand in emerging countries does not automatically reduce the export of nonemerging countries. Secondly, this intuition ignores the role of international capital flows across countries so it only provides partial general equilibrium of the economy. 


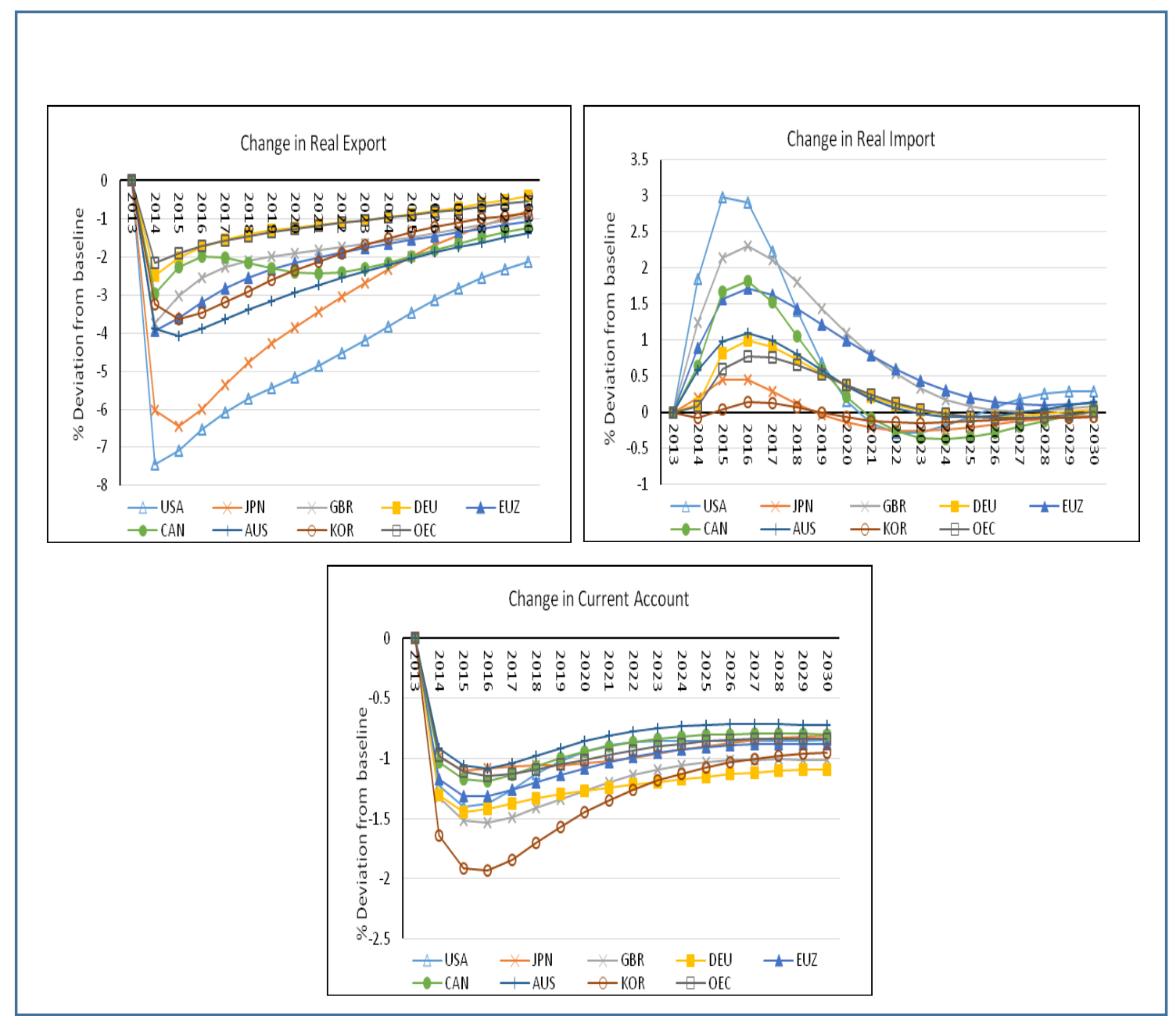

Figure 4. Real Export, Real Import, and Current Account of OECD Countries

Figure 4 shows that the current accounts in OECD countries deteriorate in the year 2014 in response to risk shock in the emerging market. This deficit of current account implies that OECD countries receive capital flow from emerging countries. Korea experiences the deepest drop of current account balance which means that export of this country falls significantly due to a decrease in demand from emerging countries. Another reason is Korea perhaps receive capital flow from emerging countries. Figure 4 shows that the current account in oil exporting and middle-east countries has become a deficit. This means that the demand for oil is decreasing in response to the economic slowdown in emerging countries.
Capital flow into the US and other OECD countries lead to the lower interest rate in these countries which has a positive effect on these countries. Lower interest rate indicates that the lower cost of capital so it can stimulate the investment. Figure 5 indicates that private investment in OECD countries increases sharply. In 2014, the US and United Kingdom experienced the largest increase in investment which are $16 \%$ and $14 \%$ respectively. On the other hand, Australia's private investment increases by less than $4 \%$ in the year 2014. Investment in OECD countries is expected to become higher than the baseline for a decade and then follows the steady-state value in the long run.

Moreover, the lower long term interest rate gives the opportunity to the household to smooth their consumption. 
Based on the intertemporal optimization behavior, the lower future interest rate leads to higher consumption. All OECD countries gain benefit from the loss of confidence in emerging countries event. Higher expected future income in OECD countries causes higher consumption. Figure 5 shows that private consumption in all OECD countries jumps up after risk shock in merging countries occurs. For a decade private consumption in OECD countries increase over time. In the long run, the level of consumption will steady above the baseline level.

In Figure 5, we can see that Korea experience a sharp increase in private consumption compared to the other OECD countries. In the year 2014, real private consumption in Korea jump to $1.8 \%$ above the baseline and then consistently increases for several years until reaches a peak at about $3 \%$ above the baseline. One possible reason is that there is a big shift in capital flow from emerging countries into Korea. Investor tends to allocate their investments to the country with less risk. Because all emerging countries become riskier then Korea might become an attractive investment destination. Capital inflow into Korea stimulates its economy so it can grow above the baseline level.

Based on the G Cubed simulation, we can see that private investment and private consumption in the OECD countries increased significantly. Therefore, the output of the economy in these countries will also increase. Figure 6 shows that output in OECD country become higher after risk shock in emerging countries is induced. After risk shock occurs, real GDP in OECD countries rise by between $0.4 \%$ and $1.2 \%$ from the baseline. Output in OECD countries is expected to remain steady above the baseline in the long term since the risk shock in emerging countries lasts forever. The US and Korea are the countries that experience the biggest gain from emerging countries crisis which is indicated by a higher increase in output. In the year 2014, real GDP in the US and Korea increased by more than $1 \%$ from the baseline and become higher in the next year.

From the G Cubed simulation, we can see that risk in emerging countries is favourable for the OECD countries. GDP of the OECD countries is predicted to be higher than the baseline in the future. However, it is predicted that national income in OECD countries will decrease in the future. This is because the lower interest rate in OECD countries causes the smaller expected return. The gain from the investment of residences decrease over time since the yield of capital gain from in OECD is smaller than the yield of capital gain from the emerging countries. Figure 6 illustrates that after risk shock is induced in emerging countries, the real GNP of OECD countries increases by $0.5 \%$ to $1.4 \%$ from the baseline where the US and Korea experience the biggest increase of national income. After several years, the GNP decreases over time. In the long term, GNP of the OECD countries is expected will decline over time and remain steady below the baseline. 

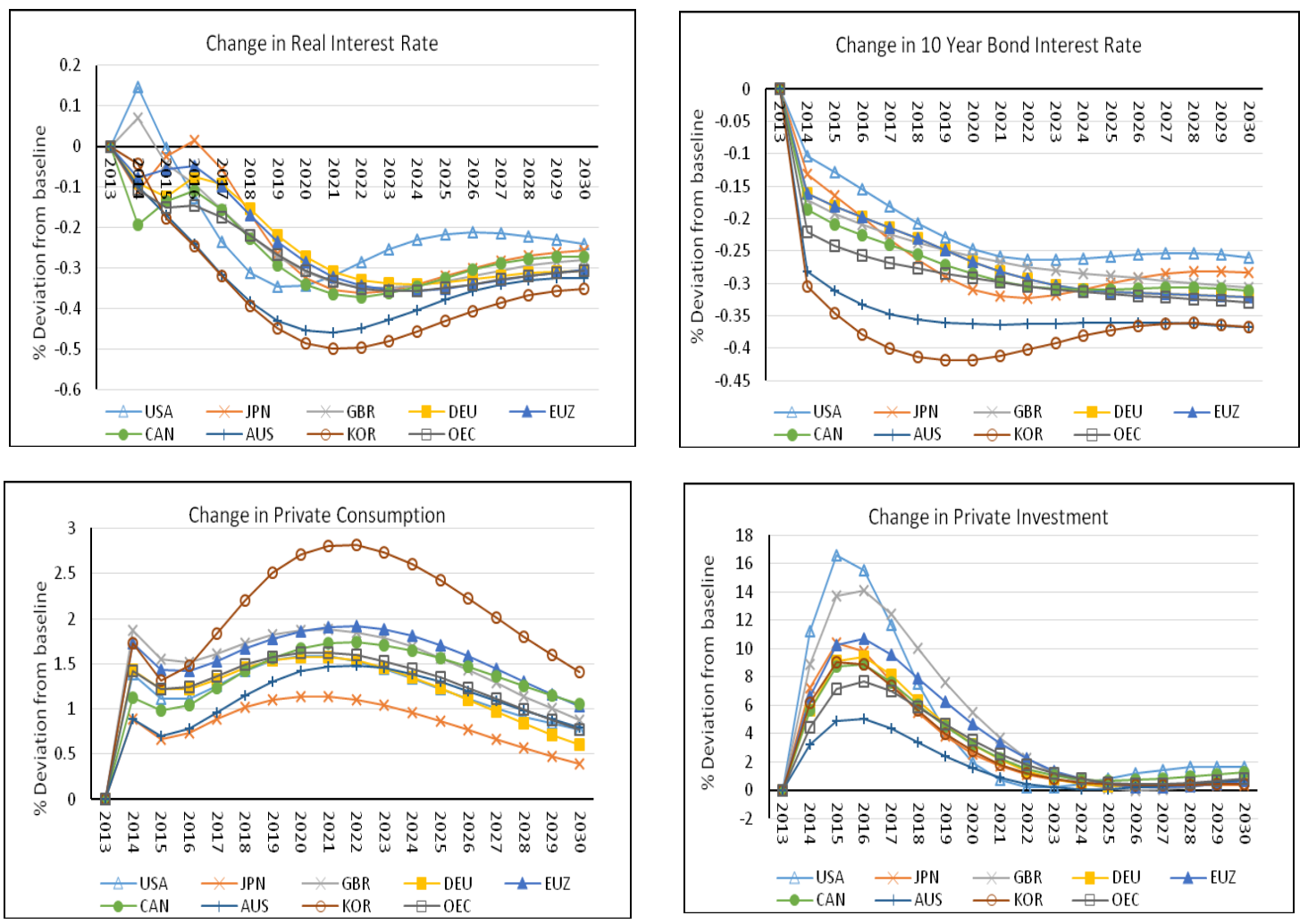

Figure 5. Real Interest Rate, 10 Year Bond Interest Rate, Private Consumption, and Private Investment of OECD Countries

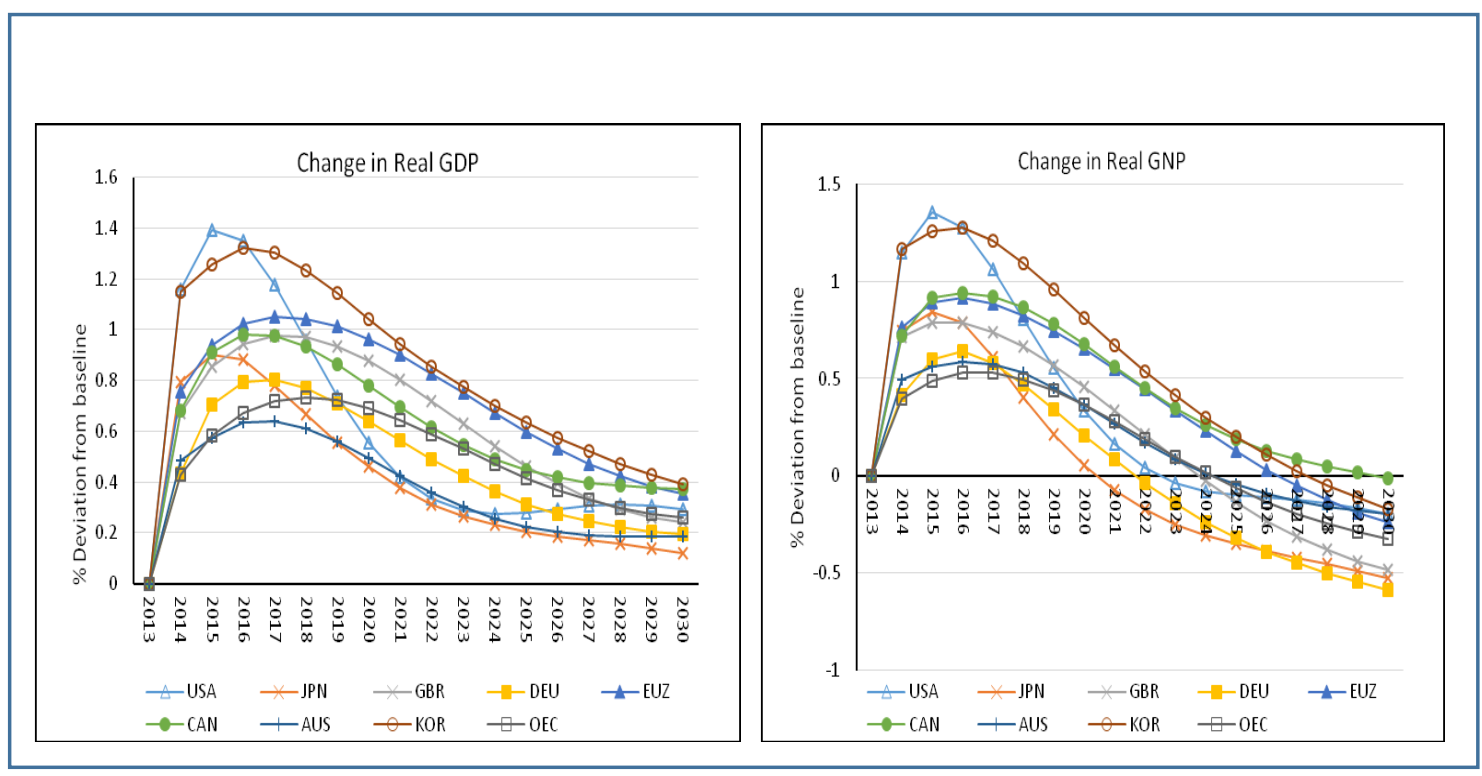

Figure 6. Real GDP and Real GNP of OECD Countries 


\section{CONCLUSION AND RECOMMEN- DATION}

The increase in risk in emerging countries requires a higher expected return of investment. Risk shock in emerging countries leads to a higher real interest rate and currency depreciation in emerging countries. In the short run, there is a significant drop in consumption and private investment in emerging countries. However, these declines do not reduce output significantly because there is a sharp increase in export due to currency depreciation. In the long run output of the emerging countries is expected steady below the baseline.

The spill over effect of the loss of confidence in emerging countries basically can be examined by analyzing international trade channels. However this analyzing cannot fully represent the transmission of shock in emerging countries Therefore, it is important to examine the international capital flows transmission between emerging countries and non-emerging countries. The simulation result indicates that international financial flow has a significant role in explaining the spill over effect of the loss of confidence in emerging countries. The increase of risk in emerging countries force the investor to shift their funds into the countries which offer higher return with less risk. This causes the big capital flow into the US and other OECD countries. In the short run there is a significant increase in private consumption and investment in OECD countries. The lower expected interest rate stimulate investment in the future. In the long run, output in OECD countries is expected to become higher than the baseline.

$\mathrm{G}$ cubed simulation result provides a comprehensive analysis of the impact of the loss of confidence in the emerging countries. In the free capital mobility regime, the role of financial capital flow is a key component to explain the transmission of the risk shock in one region to the other. Therefore, in order to minimize the impact of the shock on the economy, policymakers should consider financial capital mobility behavior in their countries. The choice of the monetary policy should be determined prudently so the economy can adapt the shock on the economy. In addition, the fundamental of the economy of a country is also important to be maintained because it can influence market perception about the risk.

However, it should be considered that the result in the model is obtained based on several sets of assumptions. It means that the result is only interpreted as an indication and direction which is cannot be translated as the exact impact of risk shock. To study the impact of risk shock more accurately in the emerging market it might need further research on each specific countries to incorporate specific characteristic of the countries that cannot be captured in macroeconomic variables data set in G Cubed Model.

\section{REFERENCES}

Allsopp, C., McKibbin, W., \& Vines, D. (2008). Fiscal consolidation in Europe: some empirical issues. In Fiscal aspects of European monetary integration (pp. 181-196). https://doi.org/10.5937/zrpfni1466181 $\mathrm{g}$

Binici, M., \& Yörüko, M. (n.d.). Capital flows in the post-global financial crisis era: implications for financial stability and monetary policy Background issues: the Great Moderation and financial. BIS Papers, (57), 319-343.

Calvo, G. A., Leiderman, L., \& Reinhart, C. M. (1996). Inflows of Capital to Developing Countries in the 1990s. Journal of Economic Perspectives, 10(2), 123-139. 
Grenville, S. (2011). The Impossible Trinity and Capital Flows in East Asia. https://doi.org/10.2139/ssrn. 1955726

McKibbin, W. (1998). Modelling Crisi in Asia. ASEAN Economic Bulletin, 15(3), 347-352.

Mckibbin, W. J. (1998). The Crisis in Asia : An Empirical Assessment ASSESSMENT (No. Discussion Papers in International Economics 136).

Mckibbin, W. J., \& Stoeckel, A. (2009). The Impact of the Global Financial Crisis on World Trade. In Economic Themes (No. 1534; Vol. 5134). https://doi.org/10.1515/ethemes-20140002

McKibbin, W. J., \& Wilcoxen, P. J. (2013). A global approach to energy and the environment: The G-cubed model. In Handbook of Computable General Equilibrium Modeling (Vol. 1). https://doi.org/10.1016/B978-0-44459568-3.00015-8

Mishra, P., Moriyama, K., N'Diaye, P., \& Nguyen, L. (2014). Impact of Fed Tapering Announcements on Emerging Markets. IMF Working Papers, 14(109), 1. https://doi.org/ 10.5089/9781498361484.001

Obstfeld, M. (2002). Exchange Rates and Adjustment: Perspectives from the New Open-Economy Macroeconomics Keynote Speech by Maurice Obstfeld. Monetary and Economic Studies, (December), 23-46.

Obstfeld, M. (2012). Financial flows, financial crises, and global imbalances. Journal of International Money and Finance, 31(3), 469-480. https://doi.org/10.1016/j.jimonfin.201 1.10 .003
Prasad, E., Rogoff, K., Wei, S. J., \& Kose, M, A. (2003). Effects on Financial Globalization on Developing Countries: Some Empirical Evidence. In Effects on Financial Globalization on Developing Countries: Some Empirical Evidence. https://doi.org/ 10.5089/9787504933096.084

Reinhart, C. M., \& Reinhart, V. R. (2003). Twin Fallacies About Exchange Rate Policy in Emerging Markets. National Bureau of Economic Research Working Paper Series, No. 9670. https://doi.org/10.3386/w9670 